\title{
Desain Kapal Pembangkit Listrik 30 Megawatt untuk Perairan di Indonesia
}

\author{
Deny Ari Setiawan \\ Departemen Teknik Perkapalan, Fakultas Teknologi Kelautan, Institut Teknologi Sepuluh Nopember \\ (ITS) \\ e-mail: deny_as@live.com
}

\begin{abstract}
Abstrak-Saat ini Indonesia mengalami kekurangan cadangan listrik. Untuk itu pemerintah menggalakan program 35000 MW guna memenuhi kebutuhan listrik nasional. Program ini rencananya akan terealisasi secara tuntas pada tahun 2019. Oleh karena itu diperlukan kapal pembangkit listrik guna membantu program pemerintah ini. Diantara daerah yang mengalami kekurangan pasokan listrik adalah Kalimantan Barat dan Lombok yaitu sebesar 26.64 megawatt dan 29.25 megawatt. Untuk itu dirancanglah kapal pembangkit listrik untuk kedua daerah tersebut yaitu sebesar 30 megawatt. Kapal yang digunakan memiliki lambung berbentuk self-propelled barge. Dari analisis teknis didapatkan ukuran utama kapal yaitu panjang $=76.071 \mathrm{~m}$, lebar $=19.845 \mathrm{~m}$, tinggi $4.704 \mathrm{~m}$, dan sarat $2.425 \mathrm{~m}$. Kemudian dari analisis ekonomis didapatkan biaya investasi awal kapal sebesar Rp $\mathbf{9 1 , 8 4 0 , 2 2 8 , 5 8 0}$.
\end{abstract}

Kata Kunci-Indonesia, cadangan listrik, kapal pembangkit listrik, self-propelled barge.

\section{PENDAHULUAN}

$\mathrm{S}$ AAT ini kebutuhan listrik Indonesia belum dapat terpenuhi $100 \%$. Oleh karena itu pemerintah Indonesia mencanangkan program 35000 megawatt guna membangun pembangkit listrik berkapasitas total 35000 megawatt hingga 2019. Program 35000 megawatt ini dilaksanakan untuk memenuhi kebutuhan listrik masyarakat di seluruh Indonesia. Hal ini tentu akan meningkatkan pertumbuhan ekonomi di luar Jawa yang sebelumnya kekurangan suplai listrik secara signifikan [1].

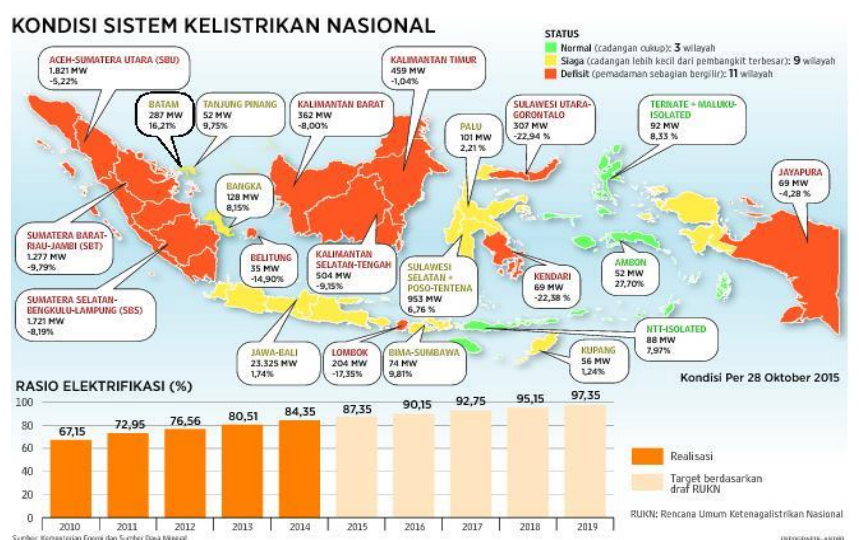

Gambar 1. Kondisi Sistem Kelistrikan Indonesia

Sumber: $\quad$ http://kompas100.print.kompas.com/2015/11/16/kondisicadangan-listrik-nasional-mengkhawatirkan/

Pemerintah telah berkomitmen untuk merealisasikan program ini dalam jangka waktu 5 tahun yang dimulai pada tahun 2014 hingga 2019. Pada jangka waktu ini, pemerintah bersama PLN dan swasta akan membangun 109 pembangkit listrik [1].

Diantara daerah yang masih kekurangan pasokan listrik menurut gambar dan tabel diatas ada daerah Kalimantan Barat dan Lombok. Saat ini keduanya dialiri listrik sebesar 362 megawatt dan 204 megawatt, hanya dapat memenuhi $92 \%$ dan $87.65 \%$ kebutuhan listrik. Sehingga dibutuhkan tambahan listrik 26.62 megawatt untuk Kalimantan Barat dan 29.25 megawat untuk Lombok untuk memenuhi $100 \%$ kebutuhan listrik kedua daerah tersebut [2].

Berkenaan dengan hal tersebut, penulis berinisiatif mendesain dua kapal pembangkit listrik 30 megawatt untuk memenuhi kebutuhan daya sekaligus memberikan surplus listrik di Kalimantan Timur dan Lombok guna membantu mendukung Program 35000 megawatt pemerintah Indonesia.

\section{URAIAN PENDAHULUAN}

\section{A. Tahap Pengumpulan dan Pengolahan Data}

Dilakukan proses pengumpulan data untuk menunjang proses analisis dalam studi ini. Kebutuhan data dibagi dalam kebutuhan data teknis dan kebutuhan data ekonomis. Proses pengumpulan data dapat berupa data primer ataupun data sekunder [3]

\section{B. Tahap Metodologi Penelitian}

Pada tahap ini dijelaskan mengenai alur pengerjaan dari studi ini.

\section{Tahap Perhitungan Teknis dan Ekonomis}

Tahap ini merupakan tahap dimana dilakukannya perhitungan aspek teknis dari desain kapal pembangkit listrik yang meliputi perhitungan hambatan, stabilitas, titik berat, lambung timbul, trim, pembuatan rencana garis dan rencana umum serta permodelan 3D kapal. Selanjutnya dilakukan analisis ekonomis tentang biaya pembangunan kapal.

\section{D.Tahap Penarikan Kesimpulan dan Saran}

Pada tahap ini dilakukan penarikan kesimpulan dan saran dari analisis yang telah dilakukan pada tahap sebelumnya [4].

\section{ANALISIS TEKNIS}

Pada bab ini akan dibahas mengenai proses penentuan jumlah muatan dan menentukan ukuran utama kapal. Selain itu juga akan di bahas mengenai perhitungan hambatan, perhitungan berat dan titik berat kapal, trim, stabilitas dan lain-lain. Dalam perhitungan tersebut harus memenuhi 
kriteria - kriteria yang harus terpenuhi, seperti kriteria IMO (International Maritime Organization). Di bab ini juga akan dibahas pembuatan Rencana Garis, Rencana Umum kapal, dan desain 3D kapal.

\section{A. Penentuan Owner Requirements}

Data-data yang dibutuhkan untuk menentukan desain dari kapal pembangkit listrik. Diantaranya kecepatan kapal, rute pelayaran dan generator yang digunakan untuk menentukan payload. Kecepatan dari kapal ditentukan sama dengan kecepatan dari rata-rata self-propelled barge yaitu 8 knots. Disini ditentukan homebase dari kapal adalah di Jakarta. Jarak Jakarta-Pontianak adalah 431 nautical miles sedangkan Jakarta-Lombok 698 nautical miles.

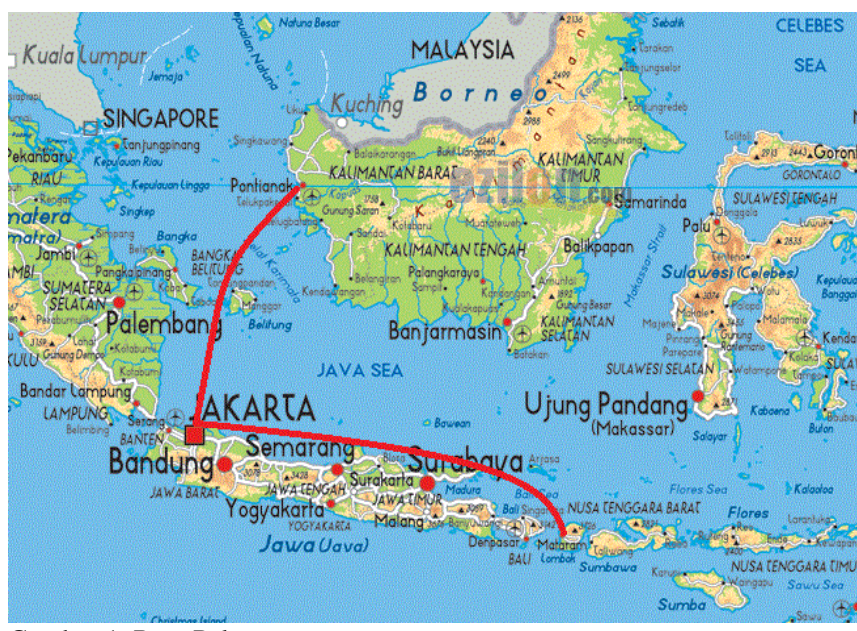

Gambar 1. Rute Pelayaran

Pada kapal ini digunakan generator ASCOT DGS-MT2500 yang berkapasitas 2.5 megawatt berjumlah 12 buah untuk memenuhi kebutuhan listrik sebesar 30 megawatt di Kalimantan Barat dan Lombok.

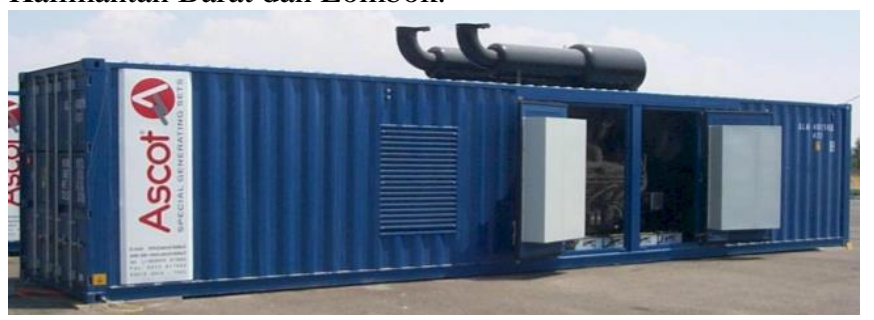

Gambar 2. Generator ASCOT DGS-MT-2500

Sumber: www.ascotnational.com

Dari generator yang digunakan dapat ditentukan payload dari kapal yaitu berat dari 12 generator, bahan bakar, dan minyak pelumas. Untuk bahan bakar dari generator direncanakan pengisian dilakukan setiap satu minggu, sehingga dibutuhkan tangki bahan bakar untuk satu minggu [5].

Tabel 1.

Payload Kapal

\begin{tabular}{lrl|}
\multicolumn{3}{c|}{ Payload Kapal } \\
\hline \hline Berat Total (x12) & 1101 ton \\
BB 12 Generator/Minggu & 1134 ton \\
Berat Minyak Pelumas (x12) & 19 ton \\
Payload & 2254 ton \\
\hline \hline
\end{tabular}

\section{B. Penentuan Ukuran Utama Awal}

Dengan menggunakan metode geosim dengan kapal pembanding Dynami III maka di dapat ukuran utama kapal sebagai berikut :

$$
\begin{array}{ll}
\mathrm{L}=76.071 \mathrm{~m} & \mathrm{~B}=19.845 \mathrm{~m} \\
\mathrm{~T}=2.425 \mathrm{~m} & \mathrm{H}=4.704 \mathrm{~m}
\end{array}
$$

\section{Perhitungan Hambatan}

Perhitungan hambatan pada desain kapal ini menggunakan metode Korean Register Barge karena lambung dari kapal ditentukan berbentuk barge. Dan didapatkan hambatan total sebesar $51.36 \mathrm{kN} \mathrm{[6].}$

\section{D.Perhitungan Berat dan Titik Berat Kapal}

Perhitungan berat dan titik berat kapal ini terdiri dari Light Weight Tonnage (LWT) dan Death Weight Tonnage (DWT). Berat dari kapal ini sendiri sebesar 3309.428 ton dengan titik berat vertikal $4.86 \mathrm{~m}$ dari baseline dan titik berat horizontal $36.10 \mathrm{~m}$. Untuk detail perhitungannya adalah sebagai berikut.

1) $L W T$

LWT adalah berat kapal kosong kapal yaitu terdiri dari berat baja, permesinan, peralatan, dan perlengkapan kapal.

a. Berat Baja

Berat baja kapal dihitung menggunakan metode post per post yaitu dengan menghitung luasan pelat kapal kemudian dikalikan dengan tebal dan masa jenis pelat. Sehingga diperoleh berat keseluruhan pelat adalah 642.674 ton. Kemudian untuk berat penegar diasumsikan seberat $30 \%$ dari berat total pelat sehingga diperoleh beratnya adalah 192.803 ton. Sehingga berat keseluruhan dari baja kapal adalah 835.476 ton.

Titik Berat Baja

$\mathrm{CKG}=0.58$

$\mathrm{KG}=\mathrm{CKG} \times \mathrm{DA}$

$$
=4.354 \mathrm{~m}
$$

LCG dari midship

Dalam \% $=-0.15+\mathrm{LCB}$

$$
=0.648 \%
$$

Dalam $\mathrm{m}=\mathrm{LCG}(\%) \times \mathrm{L}$

LCG dari FP

$$
=0.493
$$

LCGFP $=0.5 \mathrm{~L}+$ LCG dari midship

$$
=38.528 \mathrm{~m}
$$

b. Berat Permesinan

Berat permesinan terdiri dari berat mesin induk, berat generator, dan berat instalasi permesinan.

$\mathrm{W}_{\text {me }}=1.565$ ton

$\mathrm{W}_{\mathrm{au}}=0.340$ ton

$\mathrm{W}_{\mathrm{au}}=\mathrm{C}_{\mathrm{M}} \times \mathrm{BHP}^{0.7}$

$$
=76.485 \text { ton }
$$

Jadi,

$\mathrm{W}_{\mathrm{m}}=\mathrm{W}_{\mathrm{me}}+\mathrm{W}_{\mathrm{au}}+\mathrm{W}_{\mathrm{au}}$

$$
=78.390 \text { ton }
$$

Titik Berat Permesinan

Titik berat mesin dapat ditentukan dari letak mesin. Titik berat diasumsikan berada di tengah-tengah mesin.

$\mathrm{LCG}_{\mathrm{m}}=67.267 \mathrm{~m}$ dari FP

$\mathrm{KG}_{\mathrm{m}}=2.252 \mathrm{~m}$

c. Berat Peralatan dan Perlengkapan

Penentuan berat peralatan dan perlengkapan menggunakan rumus pendekatan yaitu sebagai berikut.

$\mathrm{WO} \& \mathrm{E}=\mathrm{CE} \& \mathrm{O} \times \mathrm{L} \times \mathrm{B}$

$$
=226.438 \text { ton }
$$

Titik Berat Peralatan dan Perlengkapan 
Titik berat perlengkapan diasumsikan sesuai dengan persebaran peralatan dan perlengkapan yang adap pada kapal.

$\mathrm{KGE \& O}=6.646 \mathrm{~m}$

LCGFP $=55.97$

2) $D W T$

DWT adalah berat muatan dari kapal yaitu terdiri dari berat payload dan berat consumable.

a. Berat payload

Berat payload terdiri dari berat generator pembangkit listrik, dan bahan bakarnya.

Wgen $=1101$ ton

KGgen $=7.056 \mathrm{~m}$ (diasumsikan titik berat berada pada tengah-tengah generator)

$\mathrm{LCG}=30.000 \mathrm{~m}$ dari FP (dilihat dari peletakan generator)

Wbb gen $=1153$ ton (dihitung dari konsumsi bahan bakar generator/minggu)

$\mathrm{KG}=2.818 \mathrm{~m}$

$\mathrm{LCG}=36.284 \mathrm{~m}$ dari FP

b. Berat consumable

Berat consumable terdiri dari crew, bahan bakar, oli diesel, minyak pelumas, air bersih, air kotor, oli kotor, dan bahan makanan. Dari perhitungan yang dituliskan dalam lampiran diperoleh berat consumable sebesar 11.86 ton dengan titik berat vertikal $3.25 \mathrm{~m}$ dari baseline dan titik berat horizontal $62.15 \mathrm{~m}$ dari FP.

\section{E. Perhitungan Lambung Timbul}

Freeboard atau lambung timbul merupakan selisih dari tinggi kapal dengan sarat kapal. Lambung timbul berfungsi sebagai daya apung cadangan kapal. Untuk perhitungan dapat dilihat pada lampiran dengan hasil sebagai berikut.

Tinggi minimal freeboard $=1.16 \mathrm{~m}$

Freeboard sebenarnya $\quad=3.211 \mathrm{~m}$

Dari hasil tersebut maka freeboard kapal dapat diterima karena kebih besar dari freeboard minimal dari hasil perhitungan.

\section{F. Pengujian Trim}

Pengujian trim kapal dilakukan menggunakan software Maxsurf Hydromax. Yaitu dengan memasukan model kapal dan berat serta letak komponen-komponen kapal. Diantaranya LWT kapal dan tangki-tangki dari kapal. Dari hasil pengujian menyatakan bahwa kapal telah memenuhi beberapa kriteria trim. Ini menandakan, tidak ada elemen dari kapal yang perlu diganti.

\section{G.Pengujian Stabilitas}

Pengujian stabilitas kapal dilakukan menggunakan software Maxsurf Hydromax. Yaitu dengan memasukan model kapal dan berat serta letak komponen-komponen kapal. Diantaranya LWT kapal dan tangki-tangki dari kapal.

Dari hasil pengujian menyatakan bahwa kapal telah memenuhi beberapa kriteria stabilitas. Ini menandakan, tidak ada elemen dari kapal yang perlu diganti.

\section{H.Pembuatan Rencana Garis}

Pembuatan Rencana Garis (Lines Plan) dapat dilakukan setelah ukuran utama akhir dari hasil perhitungan didapatkan. Lines Plan ini merupakan gambar proyeksi badan kapal yang dipotong secara melintang (pandangan depan), secara memanjang (pandangan samping), dan vertikal memanjang (pandangan atas). Lines plan berguna untuk mendapatkan desain kapal yang optimum. Pada pembuatan lines plan ini digunakan software Maxsurf yang kemudian dikonversikan ke software AutoCAD.

\section{Pembuatan Rencana Umum}

Setelah pembuatan Rencana Garis selesai, dapat dilakukan pembuatan Rencana Umum/General Arrangement. Rencana Umum didefinisikan sebagai perencanaan ruangan yang dibutuhkan sesuai dengan fungsi dan perlengkapannya. Ruangan-ruangan tersebut misalnya: ruang muat, ruang mesin, ruang akomodasi, superstructure (bangunan atas), dan lain-lain. Rencana Umum dibuat berdasarkan Rencana Garis yang telah dibuat sebelumnya. Dengan lines plan secara garis besar bentuk badan kapal (outline) akan terlihat sehingga memudahkan dalam mendesain serta menentukan pembagian ruangan sesuai dengan fungsinya masing-masing. Diantaranya yang perlu diperhatikan dalam pembuatan rencana umum ini adalah sebagai berikut.

\section{1) Ruang Muat}

Self Propelled-Barge (SPB) pembangkit listrik ini memeliki ruang muat untuk mengangkut bahan bakar pembangkit listrik sepanjang 61.2 meter dengan lebar 18.25 meter dan tinggi 3.12 meter yang dibagi masing-masing menjadi tiga buah tangki muat di portside dan statboard. Kemudian diatasnya diletakkan 12 buah generator pembangkit listrik dengan kapasitas 2500 megawatt.

2) Peletakan Sekat

Terdapat 3 sekat pada SPB ini, yaitu sekat ceruk buritan yang terdapat di 0.6 meter dibelakang AP, lalu sekat kamar mesin yang terdapat di 7.8 meter didepan AP, dan yang terakhir adalah sekat tubrukan yang terdapat di 2.745 meter di belakang FP.

\section{3) Perencanaan Ruangan}

Jumlah crew yang direncanakan pada adalah sejumlah 23 orang, yang mengacu kepada Peraturan Menteri Perhubungan Republik Indonesi NO: PM 25 Tahun 2015, dimana disebutkan untuk kapal dengan jumlah Gross Tonnage 1500-5000 GT jumlah crew-nya ialah 19 orang. Dimana telah diperoleh dari perhitungan tonnage bahwa jumlah GT SPB ini ialah 2081 GT. Kemudian ditambah dengan 2 orang kadet dan 2 orang teknisi pembangkit listrik.

\section{J. Permodelan 3D}

Setelah tahap pendesainan Rencana Umum selesai, maka dapat dibuat model kapal secara 3 dimensi. Pembuatan model kapal ini harus sesuai dengan ukuran utama kapal dengan bentuk lambung yang menyerupai kapal tersebut. 
BODY PLAN

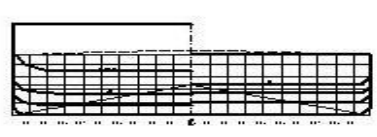

LINES PLAN

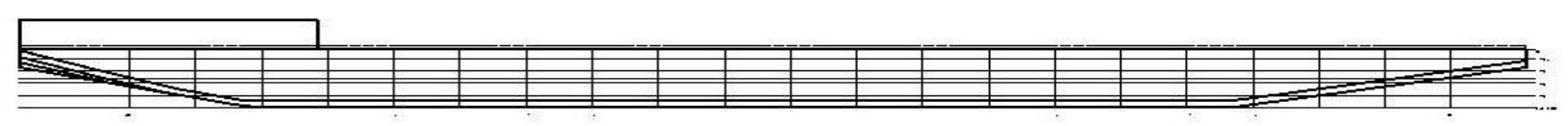

HALF BREATH PLAN

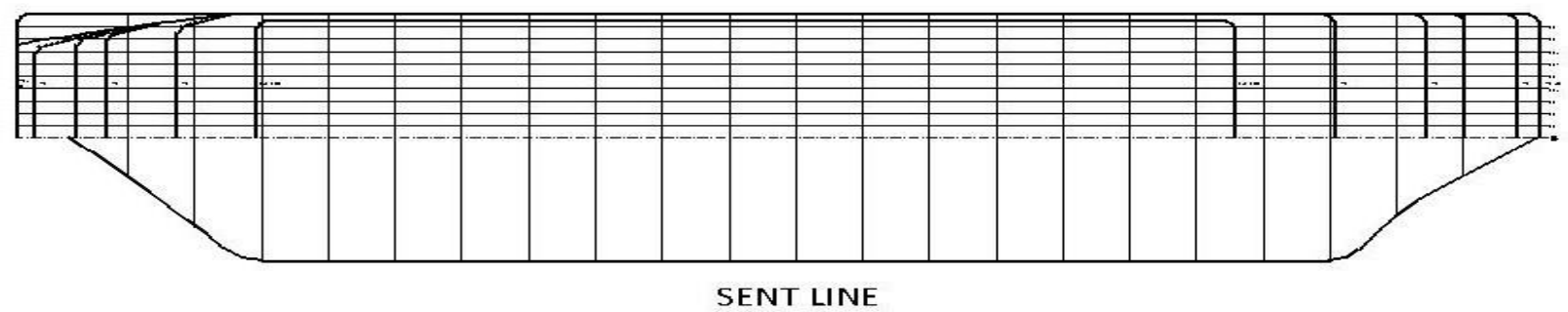

Gambar 3. Rencana Garis
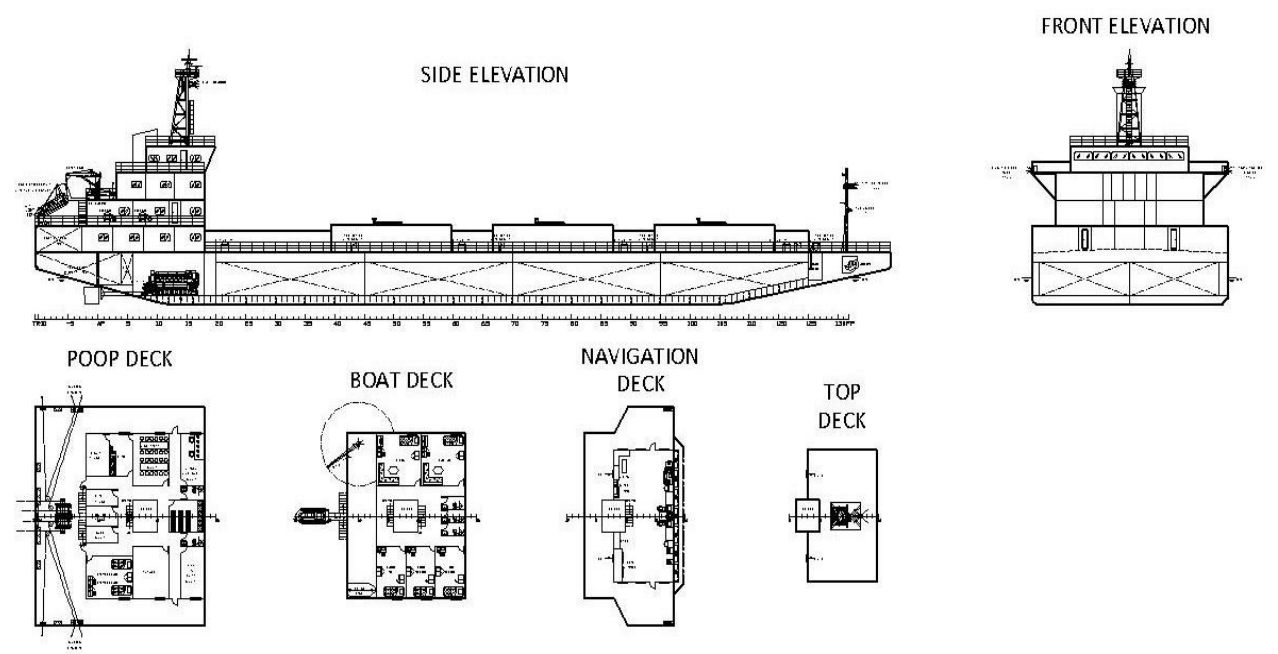

MAIN DECK

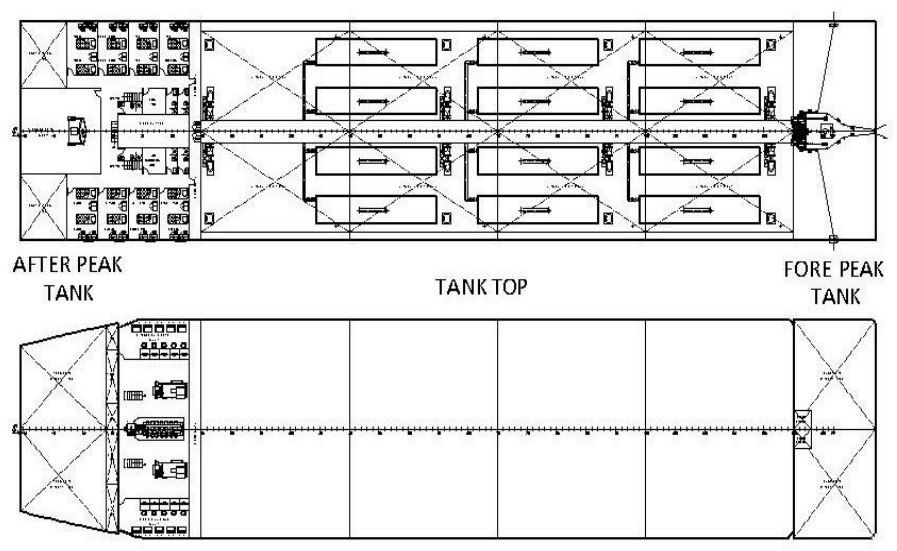




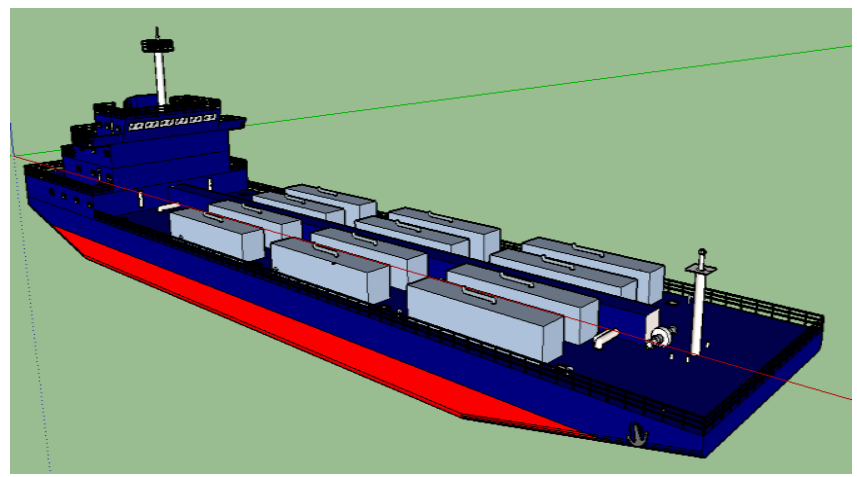

Gambar 5. Permodelan 3D Kapal

\section{J. Analisis Ekonomis}

Pada penghitungan biaya pembangunan, yang dilakukan ialah menghitung biaya total pembanguanan berdasarkan kebutuhan terhadap suatu item dikali dengan harga dari item (detail item yang diperlukan dapat dilihat pada lampiran) tersebut, karena kapal merupakan kapal konversi dicari juga biaya pembelian kapal yang memeliki ukuran identik, setelah diperoleh nilai keseluruhan biaya pembelian kapal dijumlah dengan biaya pembelian item-item yang diperlukan pada kapal. Penjumlahan keduanya nanti akan ditambah lagi dengan beberpa koreksi diantaranya koreksi keuntungan galangan sebesar $10 \%$, koreksi nilai inflansi mata uang sebesar $2 \%$, dan biaya pajak pemerintah sebesar $10 \%$, setelah diperoleh nilai keseluruhanya, lalu dijumlah maka diperoleh biaya pembangunan/konversi kapal. Sehingga didapatkan total biaya pembangunan kepal sebesar Rp91,840,228,580.

\section{KESIMPULAN}

Setelah proses desain dari Studi terselesaikan maka didapat kesimpulan sebagai berikut:

Owner Requirements

Kecepatan kapal : 8 knot

Rute pelayaran : Jakarta-Lombok, Jakarta-Kalimantan Barat

Daya pembangkit listrik : $30 \mathrm{MW}$

Ukuran Utama Kapal dan Biaya Investasi Kapal:

Lpp : $76.071 \mathrm{~m}$

B : $19.845 \mathrm{~m}$

$\mathrm{H}: 4.704 \mathrm{~m}$

$\mathrm{T}: 2.425 \mathrm{~m}$

Kecepatan Dinas : 8 knot

Investasi untuk pembangunan kapal : Rp 91,840,228,580

\section{DAFTAR PUSTAKA}

[1]

K. Indonesia, "Program Pembangkit Listrik 35000 MW by Kemenperin Indonesia," 2016. .

[2] H. Online, "Peraturan Presiden Nomor 4 Tahun 2016 by Hukum Online," 2016. [Online]. Available: http://hukumonline.com.

[3] Kamaluddin, "Desain Kapal Pembangkit Listrik Tenaga Gas Untuk Wilayah Indonesia," 2016.

[4] I. Basori, "Perancangan Awal Sightseeing-Catamaran Bertenaga Surya Untuk Perairan Paciran Lamongan," ITS, 2003.

[5] K. R. of Shipping, Rules for the Towing Survey of Barges and Tugboats. Busan, 2010.

[6] Ascot, "Ascot DGS-MT-2500," 2017. [Online]. Available: www.ascotnational.com. 